\title{
PENCITRAAN DIAGNOSTIK KANKER PARU
}

\author{
Thayalan Sukumaran \\ Program Studi Pendidikan Dokter, Fakultas Kedokteran Universitas Udayana \\ (thayalansukumaran@gmail.com)
}

\section{ABSTRAK}

Karsinoma bronkus adalah kanker yang paling umum di dunia barat, dan merupakan penyebab utama kematian terkait kanker, dimana sekitar 32\% dari semua kematian akibat kanker pada pria dan 25\% pada wanita. ${ }^{1}$ Di Amerika Serikat menyebabkan kematian lebih dari kanker usus besar, payudara dan prostat digabungan ${ }^{2}$. Dalam survei perbaikan dalam kelangsungan hidup kanker di Inggris baru-baru ini, karsinoma bronkus menunjukkan persentase penurunan terkecil dalam jumlah kematian antara 19811990 (0,2\%). Dibandingkan dengan payudara (pengurangan 11\%) dan melanoma (32\%). Keseluruhan kelangsungan hidup 5 tahun untuk kanker paru-paru didiagnosis antara 1986-1990 hanya 5,3\% (dibandingkan dengan 66\% untuk payudara dan $76 \%$ untuk melanoma). Hal ini menjadi latar belakang ahli radiologi dalam bekerja mendeteksi, mendiagnosis, gambaran, dan review dari kanker ini.

Kata Kunci: Karsinoma, bronkus, melanoma

\section{PENDAHULUAN}

Kanker paru-paru sangat umum dan dalam tahap awal, dimana $\leq 70 \%$ kasus dapat disembuhkan dengan operasi. ${ }^{4}$ Meskipun demikian, kanker paruparu tetap memiliki prognosis yang buruk. Faktor risiko utama adalah merokok, ini mudah diidentifikasi, dengan tes skrining non-invasif seperti radiografi dada dan sitologi dahak.

Tiga program skrining besar Amerika pada 1970-an yang disponsori oleh National Institute of Health, ${ }^{6-9}$ dan satu lagi di Cekoslovakia pada 1980an ${ }^{10}$ menyaring populasi berisiko tinggi dengan menggunakan radiografi dada dan analisis sputum. Semua menunjukkan peningkatan diagnosa kanker paru-paru stadium awal, akhirnya kanker dioperasi dan meningkatkan harapan hidup, sekitar 5-tahun pada kelompok kontrol. Namun tidak ada yang menunjukkan penurunan signifikan secara statistik angka kematian secara keseluruhan.

Dalam 5 tahun terakhir tiga percobaan nonrandomized computed tomography (CT) telah melaporkan beberapa data hasil screening. ${ }^{11-13}$ Temuan mereka dirangkum dalam (tabel $1 \Downarrow$ ). Di dalam tabel juga dimasukkan data awal dari dua percobaan yang sedang berlangsung di Amerika Serikat dan Jerman. Percobaan ini menunjukkan bahwa CT mendeteksi lebih banyak nodul paru-paru dari radiografi dada. Namun, hanya sebagian kecil dari nodul tersebut berubah menjadi kanker paruparu. Membedakan jinak dari nodul ganas adalah masalah utama guna menghindari jumlah biopsi yang dilakukan.

Walaupun keberlangsungan hidup dari awal penyakit ini didiagnosa, umumnya dilaporkan bukan merupakan langkah yang tepat dari tes skrining diagnostik bahkan terkadang bisa menyesatkan karena dipengaruhi bias waktu awal diagnosa, bias jarak-waktu, dan biar overdiagnosis. Meskipun CT dosis rendah dapat mendeteksi penyakit tahap awal 6-10 kali lebih sering daripada radiografi dada. ${ }^{11,15}$ Kontaminasi silang antara kelompok skrining dan kelompok kontrol penelitian juga merupakan masalah dalam penelitian besar, terutama karena masyarakat modern kini menjadi lebih sadar akan masalah kesehatan. Individu dalam percobaan kontrol mungkin khawatir bahwa mereka kehilangan pengobatan yang optimal dan bermanuver menjadi kelompok kontrol. 
Dalam upaya untuk mengatasi berbagai kesulitan tersebut,Medical Research Council di Inggris dan National Cancer Institute di Amerika Serikat saat ini uji coba prospektif, acak, percobaan dengan kontrol sebanyak 40.000 dan 88.000 pasien masing-masing menggunakan $\mathrm{CT}$ dosis rendah. ${ }^{2}$

\section{KARAKTERISKTIK RADIOLOGI BERDASARKAN TIPE} SEL

\section{Adenocarcinoma}

Adenocarcinoma mewakili 31\% kanker paru, termasuk bronchoalveolar carcinoma. ${ }^{16}$ Adenocarcinomas letaknya biasanya di perifer dan berdiamater $<4 \mathrm{~cm} .{ }^{17}$; dan hanya $4 \%$ menunjukkan kavitasi. ${ }^{18}$ Keterlibatan hila dan mediastinum terlihat pada $51 \%$ kasus di radiografi dada. ${ }^{19}$ Dan sebuah studi baru-baru ini menggambarkan dua penampilan karakteristik pada CT: bentuk kaca opacity terlokalisasi yang tumbuh secara perlahan (waktu penggandaan> 1 tahun) atau massa padat yang tumbuh lebih cepat (Waktu penggandaan $<1 \mathrm{yr}$ ). ${ }^{20}$

\section{Bronchoalveolar carcinoma}

Dianggap sebagai subtipe dari adenocarcinoma dan merupakan 2-10\% dari semua kanker paru primer. Ada tiga presentasi karakteristik: yang paling umum adalah nodul paru tunggal atau massa (41\%), dalam $36 \%$ mungkin ada penyakit multicentric atau menyebar, akhirnya, di $22 \%$ ada daerah yang berisi parenkim terkonsolidasi. ${ }^{21}$ Daerah seperti gelembung atenuasi rendah dalam massa (gbr. $1 \Downarrow)$ adalah temuan karakteristik pada CT. ${ }^{22}$ Hilus dan limfadenopati mediastinum jarang. ${ }^{23}$ Konsolidasi perifer Persistent dengan nodul terkait di lobus yang sama atau pada lobus lainnya meningkatkan kemungkinan bronchoalveolar karsinoma. ${ }^{24}$

\section{Adenosquamous carcinoma}

Karsinoma adenosquamous mewakili 2\% dari semua kanker paru-paru. ${ }^{16}$ Jenis sel ini biasanya diidentifikasi sebagai soliter, nodul perifer. Lebih dari $50 \%$ berukuran $1-3 \mathrm{~cm}$ dan kavitasi terlihat di $13 \%$. Bukti bekas luka parenkim atau fibrosis terlihat pada $50 \% .^{25}$

\section{Squamous cell carcinoma}

Karsinoma sel skuamosa merupakan 30\% dari semua kanker paru-paru. ${ }^{16}$ Tumor ini lebih sering terpusat di dalam paru-paru dan dapat tumbuh jauh lebih besar dari $4 \mathrm{~cm} .{ }^{17}$ Kavitasi (gbr. $2 \Downarrow$ ) sampai dengan $82 \% .{ }^{18}$ Mereka sering menyebabkan segmental atau kolaps paru lobar karena lokasinya di pusat dan relatif. ${ }^{26}$

\section{Small cell lung cancer}

Kanker paru-paru sel kecil (SCLC) merupakan 18\% dari semua kanker paru-paru. ${ }^{16}$ SCLC biasanya disertai dengan hila besar dan massa mediastinum kelenjar getah bening (gbr. $3 \Downarrow$ ). ${ }^{27,}{ }^{28}$ Massa parenkim noncontiguous dapat diidentifikasi hingga $41 \%$ dengan CT. ${ }^{28}$ Sebuah massa di dekat hilus adalah karakteristik dari SCLC dan tumor juga dapat menunjukkan invasi mediastinum. ${ }^{17}$

\section{Carcinoid tumour}

Tumor karsinoid merupakan 1\% dari semua kanker paru-paru. ${ }^{16}$ Tumor karsinoid Atypical cenderung lebih besar (biasanya> 2,5 cm di CT) dengan tumor karsinoid yang khas yang lebih sering dikaitkan dengan pertumbuhan endobronchial (gbr. $4 \Downarrow$ ) dan pneumonia obstruktif. ${ }^{27}$ Carcinoids cenderung terpusat daripada di perifer dan kalsifikasi terlihat pada $26-33 \%$ kasus. $^{29}$

\section{Large cell carcinoma}

Karsinoma sel besar merupakan 9\% dari semua kanker paru-paru. ${ }^{16}$ Dapat tumbuh sangat cepat, ${ }^{30}$ sampai ukuran besar, dan bermetastasis lebih awal ke mediastinum dan otak. ${ }^{31}$ Perlu dicatat bahwa ada perubahan dalam prevalensi subtipe histologis. Dua uji coba baru-baru ini telah melaporkan prevalensi besar untuk adenokarsinoma $78 \%$ dan $58 \%$ sementara karsinoma sel skuamosa hanya menyumbang $4 \%$ dan $11 \%{ }^{11,13}$

\section{SIMPULAN}

Kanker paru-paru adalah penyakit yang memiliki prognosis buruk. Kelangsungan hidup berbanding terbalik dengan satge penyakit, dan deteksi dini dan diagnosis menjadi kunci untuk mencapai kesembuhan. Pencitraan cross-sectional merupakan sarana utama penilaian radiologi. Radiografi dada 
masih penting, dan sering menunjukkan diagnosis pertama, tapi ketidakpekaan telah menyebabkan CT scan menjadi pilihan utama dalam studi skrining.

Saat ini ada masih sedikit alasan untuk memilih antara CT dan MRI dalam pembagian staging penyakit, meskipun CT lebih banyak tersedia dan lebih murah. PET pencitraan menawarkan kesensitifan untuk keganasan primer serta penyebaran penyakit, meskipun tidak $100 \%$ akurat dan hanya tersedia di beberapa rumah sakit pusat. CT scan di masa masa mendatang menjadi lebih canggih dalam desain dan fleksibilitas dan tampaknya akan tetap menjadi modalitas pencitraan utama untuk penyakit ini.

\section{DAFTAR PUSTAKA}

1. Landis SH, Murray T, Bolden S, Wingo PA. Cancer statistics. Ca: a Cancer Journal for Clinicians 1998; 48: 6-29.

2. Patz EF Jr, Goodman PC, Bepler G. Screening for lung cancer. N Engl J Med 2000; 343: 1627-1633.

3. Richards MA, Stockton D, Babb P, Coleman MP. How many deaths have been avoided through improvements in cancer survival? BMJ 2000; 320: 895-898.

4. Mountain CF. Revisions in the International System for Staging Lung Cancer. Chest 1997; 111: 1710-1717.

5. Smith IE. Screening for lung cancer: time to think positive. Lancet 1999; 354: 86-87.

6. Tockman M. Survival and mortality from lung cancer in a screening population: the Johns Hopkins study. Chest 1986; 89: 324S-326S.

7. Fontana RS, Sanderson DR, Woolner LB, Taylor WF, Miller WE, Muhm JR. Lung cancer screening: the Mayo program. J Occup Med 1986; 28: 746-750.

8. Frost JK, Ball WC Jr, Levin ML, et al. Early lung cancer detection: results of the initial (prevalence) radiologic and cytologic screening in the Johns Hopkins study. Amer Rev Respir Dis 1984; 130: 549554.
9. Melamed MR, Flehinger BJ, Zaman MB, Heelan RT, Perchick WA, Martini N. Screening for early lung cancer. Results of the Memorial Sloan-Kettering study in New York. Chest 1984; 86: 44-53.

10. Kubik A, Parkin DM, Khlat M, Erban J, Polak J, Adamec $M$. Lack of benefit from semi-annual screening for cancer of the lung: follow-up report of a randomized controlled trial on a population of highrisk males in Czechoslovakia. Int J Cancer 1990; 45: 26-33.

11. Henschke Cl, McCauley DI, Yankelevitz DF, et al. Early Lung Cancer Action Project: overall design and findings from baseline screening. Lancet 1999; 354: 99-105.

12. Kaneko M, Eguchi K, Ohmatsu H, et al. Peripheral lung cancer: screening and detection with low-dose spiral CT versus radiography. Radiology 1996; 201: 798-802.

13. Sone S, Takashima S, Li F, et al. Mass screening for lung cancer with mobile spiral computed tomography scanner. Lancet 1998; 351: 1242-1245.

14. Wan H, Karesen R, Hervik A, Thoresen SO. Mammography screening in Norway: results from the first screening round in four counties and costeffectiveness of a modeled nationwide screening. Cancer Causes Control 2001; 12: 39-45.

15. Sone S, Li F, Yang ZG, et al. Results of three-year mass screening programme for lung cancer using mobile low-dose spiral computed tomography scanner. Br J Cancer 2001; 84: 25-32.

16. Pretreatment evaluation of non-small-cell lung cancer. The American Thoracic Society and The European Respiratory Society. Amer J Respir Crit Care Med 1997; 156: 320-332.

17. Armstrong P. Neoplasms of the lungs, airways and pleura. In: Armstrong $P$, Wilson $A G$, Dee $P$, Hansell DM, eds. Imaging of Diseases of the Chest. 3rd edition. London, Mosby (Harcourt), 2000; pp. 305- 401 . 
18. Chaudhuri MR. Primary pulmonary cavitating carcinomas. Thorax 1973; 28: 354-366.

19. Woodring JH, Stelling CB. Adenocarcinoma of the lung: a tumor with a changing pleomorphic character. Am J Roentgenol 1983; 140: 657-664.

20. Aoki T, Nakata $H$, Watanabe $H$, et al. Evolution of peripheral lung adenocarcinomas: $\mathrm{CT}$ findings correlated with histology and tumor doubling time. Am J Roentgenol 2000; 174: 763-768.

21. Bonomo L, Storto ML, Ciccotosto C, et al. Bronchioloalveolar carcinoma of the lung. Eur Radiol 1998; 8: 996-1001.

22. Zwirewich CV, Vedal S, Miller RR, Muller NL. Solitary pulmonary nodule: high-resolution CT and radiologic-pathologic correlation. Radiology 1991; 179: 469-476.

23. Clark LR, Stull MA, Twigg HL. Chest case of the day. Bronchoalveolar carcinoma of the lung. Am J Roentgenol 1990; 154: 1318-1319.

24. Aquino SL, Chiles C, Halford P. Distinction of consolidative bronchioloalveolar carcinoma from pneumonia: do CT criteria work? Am J Roentgenol 1998; 171: 359-363.

25. Kazerooni EA, Bhalla M, Shepard JA, McLoud TC. 